\title{
Гистологическая классификация степени тяжести острого холецистита: хирургические последствия
}

\section{А. М. Беляев ${ }^{1}$, Н. Анджело 2 , М. Бут' ${ }^{2}$ С. Бергин ${ }^{3}$ \\ ${ }^{1}$ Городская больница, Окленд, Новая Зеландия, \\ 2Больница Норт Шора, Окленд, Новая Зеландия, \\ Факультет медицины и здравоохранения, Университет Окленда, Окленд, Новая Зеландия \\ Histology-based classification of acute cholecystitis severity: Surgical Implications}

\author{
A. M. Beliaev ${ }^{1}$, N. Angelo ${ }^{2}$, M. Booth ${ }^{2}$, C. Bergin ${ }^{3}$ \\ ${ }^{1}$ Auckland City Hospital, Auckland, New Zealand, \\ ${ }^{2}$ North Shore Hospital, Auckland, New Zealand, \\ ${ }^{3}$ Faculty of Medical and Health Sciences University of Auckland, Auckland, New Zealand
}

\section{Реферат}

Цель. Современные классификации острого холецистита (ОХ) не учитывают степень выраженности гистологического воспаления желчного пузыря.

Нами проведена оценка взаимосвязи между гистологическим воспалением желчного пузыря, риском конверсии лапароскопической холецистэктомии КЛХ) в Открытую операцию (и тяжестью периоперационных осложнений, а также разработана гистологическая классификация степени тяжести ОХ.

Материалы и методы. Ретроспективное когортное исследование основано на клинических наблюдениях за 1762 пациентами, которым была выполнена лапароскопическая холецистэктомия. Из них у 472 пациентов диагноз ОХ был подтвержден при гистологическом исследовании.

Результаты. У пациентов с активным хроническим холециститом и с острым отечным холециститом риск КлХ был выше более чем в пять раз по сравнению с пациентами с нормальным желчным пузырем и с хроническим холециститом: отношение шансов (ОШ) = 5,1; 95\% доверительный интервал (Ди) 3,5-7,6; p <0,00005. Пациенты с острым некротическим холециститом имели 10-кратное увеличение риска КЛХ (ОШ = 10,9; 95\% ДИ 6,1-19,1; p <0,00005). Пациенты с острым гангренозным и гнойным холециститом имели более чем 11 -кратное увеличение риска КЛХ (ОШ = 11,9 ; 95\% ДИ 6,8-20,5; p <0,00005). Пациенты с перихолецистическим абсцессом или перфорацией желчного пузыря имели в 25-кратное увеличение риска КЛХ (ОШ = 25,2; 95\% ДИ 5,2 - 129,2; p <0,00005). Пациенты с умеренно тяжелой степенью гистологического воспаления желчного пузыря имели в два раза выше риск КЛХ, чем пациенты с легкой степенью гистологического воспаления (ОШ = 2,0; $95 \%$ Ди 1,3-3,1; $\mathrm{p}=0,003)$, них была большей продолжительность операции и более высокая частота и тяжесть периоперационных осложнений.

Выводы. Повышение степени тяжести гистологического воспаления желчного пузыря соответствует большему риску КЛХ, увеличению частоты и тяжести периоперационных осложнений.

Ключевые слова: лапароскопическая холецистэктомия; острый холецистит; классификация.

\section{Abstract}

Objective. Current classifications of acute cholecystitis (AC) severity do not relate clinical to histological severity of AC. The aims of our study were to assess the relationship between histologic gallbladder inflammation, risk of CTO and severity of perioperative complications, and to propose a histology-based clinical classification for AC severity.

Materiale and methods. This was a retrospective cohort study of 1762 patients who had laparoscopic cholecystectomy (LC), 472 of whom had AC confirmed on histological examination.

Results: Patients with active chronic cholecystitis and those with acute edematous cholecystitis had more than a five-fold increase in odds of CTO compared with patients with normal gallbladders and those with chronic cholecystitis, $(\mathrm{OR}=5.1 ; 95 \%$ CI, $3.5-7.6 ; \mathrm{p}<0.00005)$. Patients with acute necrotizing cholecystitis had a ten-fold increase in CTO odds (OR $=10.9 ; 95 \%$ CI, $6.1-19.1 ; \mathrm{p}<0.00005)$. Patients with acute gangrenous and suppurative cholecystitis had more than 11 -fold increase in CTO odds (OR $=11.9 ; 95 \% \mathrm{CI}, 6.8-20.5 ; \mathrm{p}<0.00005)$ and those with pericholecystic abscess or gallbladder perforation had 25 times higher odds of CTO (OR $=25.2 ; 95 \%$ CI, $5.2-129.2 ; \mathrm{p}<0.00005)$. Patients with moderate-severe AC have twice the risk of CTO that patients in the mild group have $(\mathrm{OR}=2.0 ; 95 \% \mathrm{CI}: 1.3-3.1 ; \mathrm{p}=0.003)$, longer durations of surgery and higher rates and severity of perioperative complications.

Conclusion. Increasing severity of histologic gallbladder inflammation corresponds with greater risk of CTO, higher rates and severity of perioperative complications.

Keywords: laparoscopic cholecystectomy; acute cholecystitis; classification 


\section{Introduction}

The prevalence of cholelithiasis in an adult Western population is estimated to be around 15\% to 20\% [1]. In the USA, this means that approximately 12 million people aged between 20 and 74 years have gallstones [1]. Annually 1\% to 2\% of these people will develop right upper quadrant pain and present to hospital $[2,3]$. Twenty percent of these patients will be diagnosed with acute cholecystitis (AC), which, in elderly and very sick patients, is associated with 2-3\% mortality [4, 5].

Laparoscopic cholecystectomy (LC) is now the "gold standard" surgical procedure for treating symptomatic gallbladder stone disease including AC [6]. To predict potential difficulties during LC, the 2007 and updated 2013 and 2018 Tokyo guidelines (TG07/TG13/TG18) were developed based on clinical and bio-inflammatory indicators of gallbladder inflammation [7-9]. According to TG13/TG18 criteria, LC should be a straight forward and safe operation in patients with mild AC, whereas in patients with moderate-severe AC, minimally invasive surgery can be difficult and more risky [8]. However, TG13/TG18 guidelines for AC do not use an objective measure of surgical difficulty such as CTO in the classification of severity. Also, TG13/TG18 grades of AC severity lack gallbladder histological correlates [8, 9]. Ambe et al. questioned the accuracy of the TG13 severity grades in predicting the surgical complexity of LC and concluded that TG13 grades tended to underestimate the severity of gallbladder inflammation in mild AC and overestimate the difficulty of LC in patients with moderate AC [10]. In addition, these grading systems have not considered histologic active chronic cholecystitis (aka acute on chronic cholecystitis) as a variant of AC.

In a large multicentre retrospective study conducted in Japan and Taiwan that involved 5459 consecutive patients who underwent cholecystectomy, acute on chronic cholecystitis was the most common (36\%-22\%) histologic variant of AC [11].

Our clinical ability to predict the severity of gallbladder inflammation and operative difficulty is based on patients' history of illness, vital signs, physical examination, laboratory blood tests, and imaging studies such as abdominal ultrasound, computed tomography and magnetic resonance imaging [12-17]. These scans can show gallbladder wall thickening, pericholecystic fluid and pericholecystic abscesses among other manifestations of gallbladder inflammation [12].

Recently, in the same group of AC patients that are in the current study, we showed that inflammatory biomarkers including C-reactive protein (CRP) and neutrophil-to-lymphocyte ratio (NLR) were associated with severity of histological gallbladder inflammation [18, 19]. CRP is an acute phase protein produced by the liver in response to increased secretion of the cytokine interleukin- 6 by macrophages in infection, inflammation, and injury [20]. Concentrations of CRP and NLR rise proportionally with increasing histologic severity of AC $[18,19]$. In predicting the severity of gallbladder inflammation, these findings can help clinicians to formulate the most effective management strategy. However, there are no studies demonstrating the relationship between histological findings and surgical risk in patients with AC.
Our study hypothesis was that the severity of histologic gallbladder inflammation corresponds with the clinical severity of AC and surgical difficulty. The aim of our study was two-fold; firstly, to assess the relationship between histologic gallbladder inflammation, risk of CTO and severity of peri-operative complications. Secondly, we aimed to establish a histology-based clinical classification for AC severity.

\section{Methods}

This was a retrospective cohort study of 1959 patients who underwent cholecystectomy at a tertiary referral hospital in New Zealand between May 2004 and June 2009. Patients were excluded if they had open liver resection with cholecystectomy, open cholecystectomy (OC), conversion to open surgery for common bile duct (CBD) exploration or gallbladder cancer. Clinical data were derived from patients' electronic outpatient clinic visits, hospital discharge summaries, operation notes, blood tests, radiological reports and histology reports. Primary end-point of outcome was histologic classification of excised gallbladders.

In our review the following morphological features were used for the histological classification of cholecystitis:

Chronic cholecystitis: thickening of the gallbladder wall due to fibrosis and muscular hyperplasia, a chronic interstitial inflammatory cell infiltrate, epithelial lined sinuses and metaplastic epithelial changes.

Active chronic cholecystitis: as for chronic cholecystitis but with additional neutrophilic mucosal infiltrates.

Acute edematous cholecystitis: vascular congestion and dilatation in the gallbladder wall, accompanied by interstitial and subserosal edema with scattered areas of interstitial haemorrhage.

Acute necrotizing cholecystitis: as for edematous cholecystitis but with an acute inflammatory response and/or necrosis mostly confined to the mucosa.

Acute gangrenous cholecystitis: extensive replacement of the mucosa and muscularis propria by necrotic debris, neutrophils and granulation tissue.

Acute suppurative cholecystitis: areas of tissue necrosis and suppuration extending beyond the mucosa into the gallbladder wall.

Complicated AC: Any AC with accompanying pericholecystic abscess or gallbladder perforation that was walled off by peritoneal or omental tissues. Gallbladder perforation was characterized by transmural extension of gangrenous or suppurative cholecystitis with spill over of the exudate onto the serosal surface.

The secondary points of outcome for this study were rate of conversion of laparoscopic cholecystectomy to open surgery (CTO), which was used as a proxy measure of surgical difficulty of LC, major bile duct injury, bowel injury, duration of surgery and the rate and severity of peri-operative complications. Major bile duct injury corresponds to type D and E of the Strasberg's classification [21]. Peri-operative complications were graded according to the Clavien-Dindo classification into non-life-threatening (Clavien-Dindo grades 1-III) 
and life-threatening complications (Clavien-Dindo grades IV and V) [22].

Based on severity and depth of histologic gallbladder inflammation, patients were divided into 5 groups. Patients with normal gallbladders and those with chronic cholecystitis were used as the reference groups. Patients with active chronic and acute edematous cholecystitis were grouped together because they had minimal evidence of acute inflammation. Patients with acute necrotizing cholecystitis had established inflammation that was confined mainly to the mucosa. Patients with acute gangrenous and suppurative cholecystitis had acute inflammation involving the entire gallbladder wall. In patients with pericholecystic abscess and gallbladder perforation, inflammation extended through the gallbladder wall.

A subgroup analysis was performed to assess the relationship between each histologic classification and CTO. Patients with low odds of CTO were assigned to the mild AC group, whereas patients with more advanced acute inflammatory gallbladder histologic findings and higher risk of CTO were allocated to the moderate-severe AC group.

This study was registered by Our Institutional Research Office as an audit (RM080712419).

\section{Statistical analysis}

Statistical analysis was performed with Stata/SE (version 13) software package (StataCorp LP, College Station, TX, USA). Continuous variables were analysed with the skewness and kurtosis test for the normality of data distribution. Continuous variables were expressed as median and range and analysed with the two-sample Wilcoxon rank-sum test if they had non normal distribution and as mean and standard deviation for normally distributed data. Categorical variables were presented as an absolute number and percentage (\%) and analysed using chi-square test. Logistic regression was used to estimate adjusted and unadjusted odds ratio of CTO. P-values less than 0.05 were accepted as statistically significant.

\section{Results}

Of the 1959 patients identified over the 5 years, 197 were excluded. The remaining 1762 patients who met the eligibility criteria were included in this study. Patients' demographic and clinical characteristics are presented in Table 1.

Among the 1762 patients who underwent LC there were 185 (10.5\%) patients who had CTO. Eighteen (1\%) patients had concomitant laparoscopic procedures performed including seven gastric bypass, six fundoplications, two had liver cysts de-roofed and one each had gastric resection, appendicectomy and inguinal hernia repair. Twenty eight (1.6\%) LC patients also had paraumbiliral, epigastric or anterior abdominal wall incisional hernia repair with sutures using an open technique and 8 (0.5\%) patients had open mesh repair of paraumbilical, unilateral inguinal or anterior abdominal wall incisional hernia.

Relationship between histologic severity of gallbladder inflammation and CTO

Analysis of the relationship between histologic severity of gallbladder inflammation and CTO demonstrated a sta-

\begin{tabular}{|c|c|c|}
\hline \multicolumn{3}{|c|}{ Overall characteristics of the study patients } \\
\hline \multicolumn{2}{|c|}{ Characteristics } & $\begin{array}{l}\text { Study patients, } \\
\mathrm{N}=1762, \mathrm{n}(\%)\end{array}$ \\
\hline \multicolumn{2}{|c|}{ Age (median, range), years } & $52(15-93)$ \\
\hline \multicolumn{3}{|l|}{ Gender, n (\%) } \\
\hline \multicolumn{2}{|l|}{ Male } & 707 (43.7) \\
\hline \multicolumn{2}{|l|}{ Female } & $992(56.3)$ \\
\hline \multicolumn{3}{|l|}{ Ethnicity, n (\%) } \\
\hline \multicolumn{2}{|l|}{ Caucasian } & $1301(73.8)$ \\
\hline \multicolumn{2}{|l|}{ Maori } & $130(7.4)$ \\
\hline \multicolumn{2}{|l|}{ Pacific Islander } & $81(4.6)$ \\
\hline \multicolumn{2}{|l|}{ Asian } & $132(7.5)$ \\
\hline \multicolumn{2}{|l|}{ Others§ } & $118(6.7)$ \\
\hline \multicolumn{3}{|l|}{ Admission type } \\
\hline \multicolumn{2}{|l|}{ Elective } & $883(50.1)$ \\
\hline \multicolumn{2}{|l|}{ Acute } & 879 (49.9) \\
\hline \multicolumn{2}{|l|}{ Cholelithiasis } & $1642(93.2)$ \\
\hline \multicolumn{3}{|l|}{ Comorbidities } \\
\hline \multicolumn{2}{|l|}{ Hypertension } & $454(25.8)$ \\
\hline \multicolumn{2}{|l|}{ TIA/stroke } & $44(2.5)$ \\
\hline \multicolumn{2}{|l|}{ Angina } & $101(5.7)$ \\
\hline \multicolumn{2}{|l|}{ Previous MI } & $83(4.7)$ \\
\hline \multicolumn{2}{|c|}{ Cardiac arrhythmia } & 87 (4.9) \\
\hline \multicolumn{2}{|l|}{ Heart failure } & $35(2.0)$ \\
\hline \multicolumn{2}{|c|}{ Diabetes mellitus } & $171(9.7)$ \\
\hline \multicolumn{2}{|c|}{ Previous abdominal operation, $\mathrm{n}(\%)$} & $373(21.2)$ \\
\hline \multicolumn{2}{|c|}{$\begin{array}{l}\text { Number of previous abdominal } \\
\text { operations (median,range) }\end{array}$} & $1(1-5)$ \\
\hline \multicolumn{3}{|l|}{ ASA score, $n(\%)$} \\
\hline \multicolumn{2}{|l|}{1} & $555(31.5)$ \\
\hline \multicolumn{2}{|l|}{ II } & 891 (50.6) \\
\hline \multicolumn{2}{|l|}{ III } & 297 (16.9) \\
\hline \multicolumn{2}{|l|}{ IV } & $18(1.0)$ \\
\hline V & & $1(0.1)$ \\
\hline Abbreviations. & $\begin{array}{l}\text { ASA score, American } \\
\text { score. } \\
\S \text { includes Indians, Af } \\
\text { with an unidentified }\end{array}$ & $\begin{array}{l}\text { Anesthesiologists } \\
1 \text { patients }\end{array}$ \\
\hline
\end{tabular}

tistically significant association (Pearson $\mathrm{chi}^{2}(6)=208.172$, $\mathrm{p}<0.0005$ ) (Table 2).

Patients with histologically normal gallbladders and those with chronic cholecystitis had similar low risks of CTO $(\mathrm{OR}=$ 2.1; 95\% CI, 0.6-18.8, p = 0.269). Patients with active chronic cholecystitis demonstrated more than a five-fold increase in risk of CTO compared with patients with chronic cholecystitis (OR $=5.3$; $95 \% \mathrm{CI}, 3.4-8.1, \mathrm{p}<0.00005)$.

A subgroup analysis of the 472 patients with AC including those with active chronic cholecystitis showed that patients with histologic findings of acute edematous cholecystitis and those with active chronic cholecystitis had similar risks of CTO $(\mathrm{OR}=1.3,95 \% \mathrm{CI}, 0.6-2.7 ; \mathrm{p}=0.46)$, whereas patients with histologic findings of acute necrotizing, gangrenous and suppurative cholecystitis, acute cholecystitis with gallbladder perforation and biliary peritonitis or pericholecystic abscess had statistically higher risks of CTO, $(\mathrm{OR}=2.5$; $95 \% \mathrm{CI}, 1.1-5.8$; $\mathrm{p}=0.012 ; \mathrm{OR}=2.8 ; 95 \% \mathrm{CI}, 1.3-6.2 ; \mathrm{p}=0.005 ; \mathrm{OR}=5.9 ; 95 \%$ CI, 1.1 - 32.9; $\mathrm{p}=0.008$ ), respectively (Table 3). 


\begin{tabular}{|c|c|c|}
\hline \multicolumn{3}{|c|}{$\begin{array}{l}\text { Conversion rate for each histologic } \\
\text { classification }\end{array}$} \\
\hline \multicolumn{2}{|c|}{ Gallbladder histopathology } & $\begin{array}{c}\text { СTO rate } \\
(\%)\end{array}$ \\
\hline \multicolumn{2}{|c|}{$\begin{array}{l}\text { Normal gallbladder/gallbladder polyp/papillary } \\
\text { hyperplasia/gallbladder adenomyosis }\end{array}$} & $\begin{array}{l}2 / 87 \\
(2.3)\end{array}$ \\
\hline \multicolumn{2}{|c|}{ Chronic cholecystitis } & $\begin{array}{l}59 / 1203 \\
(4.9)\end{array}$ \\
\hline \multicolumn{2}{|c|}{ Acute oedematous cholecystitis } & $\begin{array}{l}14 / 80 \\
(17.5)\end{array}$ \\
\hline \multicolumn{2}{|c|}{ Active chronic cholecystitis } & $\begin{array}{c}48 / 225 \\
(21.3)\end{array}$ \\
\hline \multicolumn{2}{|c|}{ Acute necrotizing cholecystitis } & $\begin{array}{l}27 / 77 \\
(35.1)\end{array}$ \\
\hline \multicolumn{2}{|c|}{ Acute gangrenous/suppurative cholecystitis $¥$} & $\begin{array}{l}30 / 81 \\
(37.0)\end{array}$ \\
\hline \multicolumn{2}{|c|}{$\begin{array}{l}\text { Pericholecystic abscess/acute cholecystitis with } \\
\text { gallbladder perforation }\end{array}$} & $\begin{array}{l}5 / 9 \\
(55.6)\end{array}$ \\
\hline Abbreviation. & \multicolumn{2}{|c|}{$\begin{array}{l}\text { CTO, conversion of laparoscopic } \\
\text { cholecystectomy to open surgery. } \\
¥ \text { includes one case of gallbladder torsion. }\end{array}$} \\
\hline
\end{tabular}

Relationship between the depth and severity of AC and CTO

We have shown that patients with active chronic cholecystitis and those with acute edematous cholecystitis had more than a five-fold increase in risk of CTO than patients with either normal gallbladders or those with chronic cholecystitis $(\mathrm{OR}=5.1$; 95\% CI, 3.5 - 7.6; $\mathrm{p}<0.00005)$. We showed a tenfold increase in patients with acute necrotizing cholecystitis $(\mathrm{OR}=10.9 ; 95 \% \mathrm{CI}, 6.1-19.1 ; \mathrm{p}<0.00005)$, more than 11 -fold increase in those with acute gangrenous and suppurative cholecystitis $(\mathrm{OR}=11.9 ; 95 \% \mathrm{CI}, 6.8-20.5 ; \mathrm{p}<0.00005)$ and those with pericholecystic abscess and gallbladder perforation had 25 times higher odds of CTO $(\mathrm{OR}=25.2 ; 95 \% \mathrm{CI}, 5.2-129.2$; $\mathrm{p}<0.00005)$ (Table 4).

Patients with acute necrotizing cholecystitis had more than twice the risk of CTO as those patients who had active chronic and acute edematous cholecystitis, (OR $=2.1$; 95\% CI, 0.5 $-2.2 ; \mathrm{p}=0.006$ ). Those with acute gangrenous or suppurative cholecystitis and those with pericholecystic abscess and gallbladder perforation also had more than twice the risk of CTO (OR $=2.3$; 95\% CI, 1.3-4.0; $\mathrm{p}=0.002)$ and 4.9 times the risk of CTO (95\% CI, $1.01-25.3 ; \mathrm{p}=0.011)$, respectively (Table 4). The risk of CTO was similar for patients with acute necrotizing, acute gangrenous and suppurative cholecystitis and those with either pericholecystic abscess formation or gallbladder perforation.

Histology-based clinical classification of AC

Based on the histologic findings of $\mathrm{AC}$ and similar risk of CTO, patients with acute oedematous cholecystitis and those with active chronic cholecystitis comprised the mild AC category. In contrast, patients with acute necrotizing, gangrenous/suppurative cholecystitis, AC with gallbladder perforation, biliary peritonitis or pericholecystic abscess had significantly higher risk of CTO and were grouped into the histologically moderate-severe AC category. Demographic and clinical characteristics of patients within each grade of AC are presented in Table 5.

These two groups were unbalanced on variables of age, gender, hospital admission type, angina, diabetes mellitus and the American Association of Anaesthesiology score. After adjusting for these variables, those patients in the moderate-severe histologic categories demonstrated a two-fold increase in risk of CTO compared with those in the mild category (adjusted OR=2.0; 95\% CI: 1.3-3.1; $\mathrm{p}=0.003$ ). Patients with moderate-severe AC also had longer durations of surgery (median $130 \mathrm{~min}$, range: $70-320 \mathrm{~min}$ ) than patients with mild AC (median 106 min, range $42-255$ min) $(p<0.005)$. In addition, there were different rates and severity of peri-operative of complications.

Sixty five (38.9\%) patients with histologic moderate-severe AC and 72 (23.6\%) patients with mild AC developed peri-operative complications ( $\mathrm{p}<0.0005) .10$ of $65(15.4 \%)$ patients with moderate-severe AC developed life-threatening peri-operative complications (ASA score IVa-V) with one death, whereas only 3 of 72 (4.2\%) patients in the mild group, had life-threatening complications but with no fatalities (Pearson $\left.\mathrm{chi}^{2}(1)=5.005, \mathrm{p}=0.025\right)$. Seven $(4.2 \%)$ patients from the moderate-severe AC group and 2 (0.7\%) patients from the mild AC group developed major bile duct injury $\left(\mathrm{Chi}^{2}(1)=7.21 ; \mathrm{p}=\right.$ 0.007). Intraoperative bowel injury was also more common in the moderate-severe AC group. Three (1.8\%) patients from

\begin{tabular}{|c|c|c|c|c|c|}
\hline Table 3. & \multicolumn{5}{|c|}{$\begin{array}{l}\text { Conversion of laparoscopic cholecystectomy to open surgery in each histologic classification of acute } \\
\text { cholecystitis }\end{array}$} \\
\hline \multicolumn{2}{|c|}{ Gallbladder histopathology } & $\begin{array}{l}\text { CTO rate, } \\
(\%)\end{array}$ & OR & $95 \% \mathrm{Cl}$ & P-value* \\
\hline \multicolumn{2}{|c|}{ Acute oedematous cholecystitis } & $\begin{array}{l}14 / 80 \\
(17.5)\end{array}$ & 1 & - & - \\
\hline \multicolumn{2}{|c|}{ Active chronic cholecystitis } & $\begin{array}{l}48 / 225 \\
(21.3)\end{array}$ & 1.3 & $0.6-2.7$ & 0.46 \\
\hline \multicolumn{2}{|c|}{ Acute necrotizing cholecystitis } & $\begin{array}{l}27 / 77 \\
(35.1)\end{array}$ & 2.5 & $1.1-5.8$ & 0.012 \\
\hline \multicolumn{2}{|c|}{ Acute gangrenous/suppurative cholecystitis $¥$} & $\begin{array}{l}30 / 81 \\
(37.0)\end{array}$ & 2.8 & $1.3-6.2$ & 0.005 \\
\hline \multicolumn{2}{|c|}{$\begin{array}{l}\text { Acute cholecystitis with gallbladder perforation and biliary } \\
\text { peritonitis/pericholecystic abscess }\end{array}$} & $\begin{array}{l}5 / 9 \\
(55.6)\end{array}$ & 5.9 & $1.1-32.9$ & 0.008 \\
\hline \multicolumn{6}{|c|}{$\begin{array}{ll}\text { Abbreviations. } & \text { CTO, conversion of laparoscopic cholecystectomy to open surgery; OR, odds ratio; } \mathrm{Cl} \text {, confidence interval. } \\
& ¥ \text { includes one case of gallbladder torsion. }\end{array}$} \\
\hline
\end{tabular}




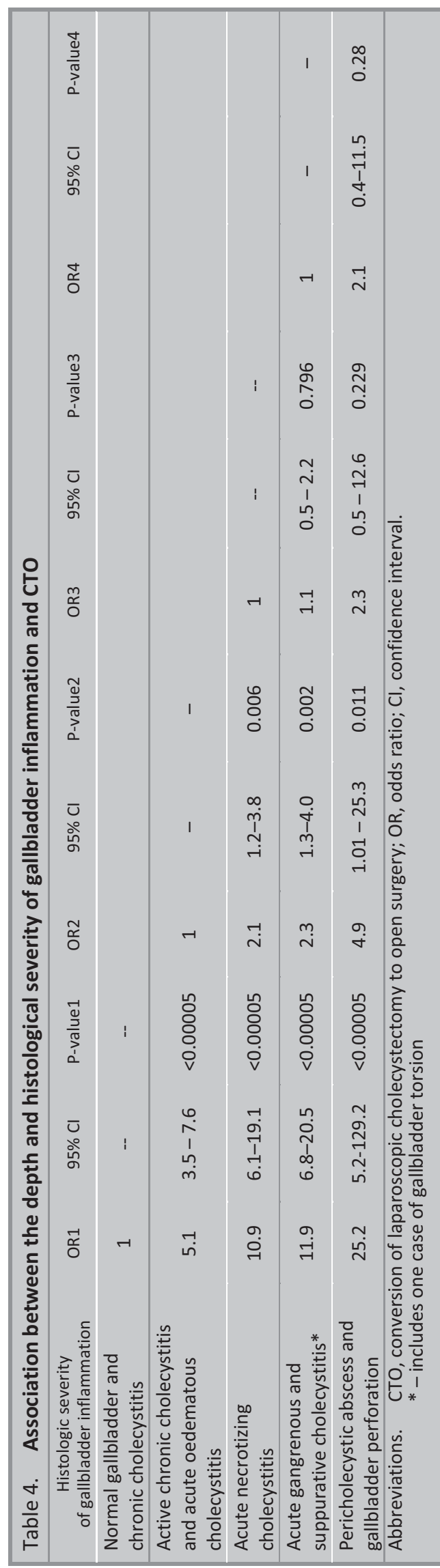

the moderate-severe $\mathrm{AC}$ group and no patients from the mild AC group suffered intraoperative bowel injury $\left(\mathrm{chi}^{2}(1)=5.51 ; \mathrm{p}=0.019\right)$.

\section{Discussion}

For the first time we have demonstrated an association between histologic severity of gallbladder inflammation and surgical risk in patients with AC. We have previously shown how these histologic categories can be predicted with increasing levels and number of raised inflammatory markers $[18,19]$. Therefore, preoperative inflammatory markers can help to establish clinical severity of patients presenting with AC and thereby predict surgical difficulty. Recently, Moloney et al. also demonstrated that patients with preoperative NLR greater than 3 had longer durations of surgery, higher rates of CTO and prolonged lengths of hospital stay [14].

Since LC was introduced into clinical practice in the late 1980's, it has surpassed conventional OC as the procedure of choice in the surgical management of gallbladder disease [5]. The main limitations of LC are; lack of a 3-dimensional view, a narrow field of laparoscopic vision, insufficient tactile sensation due to manipulation with long laparoscopic instruments and difficulties with instruments placement and maneuvering [23]. These limitations predispose patients undergoing LC to potential organ injury, especially in AC [24, 25]. To prevent such injury, safety CTO is advised [26].

An attempt to predict more difficult LC on the basis of AC severity was first made in TG07 [7]. However, neither TG07, TG13 nor TG18 criteria provide objective measures of surgical difficulty such as CTO. Also, some of the individual TG13/TG18 severity grading criteria have been shown to be inaccurate in predicting surgical difficulty. Asai et al. showed that elevation in WCC $\left(>18.0 \times 10^{9} / \mathrm{L}\right)$ did not predict risk of CTO [16]. AC patients with WCC $>18.0 \times 10^{9} / \mathrm{L}$ had a similar CTO risk as those with WCC $\leq 18.0$ $\times 10^{9} / \mathrm{L}(\mathrm{OR}=1.1 ; 95 \% \mathrm{CI}: 0.3-3.3 ; \mathrm{p}=0.511)$.

The relationship between TG13 severity grades and gallbladder histologic inflammation was investigated by P. Ambe et al. [10]. They found more than $40 \%$ of their patients who were classified as Grade 1 by TG13 criteria had histologic evidence of either acute necrotizing or gangrenous cholecystitis with complicated perioperative courses. The authors concluded that the TG13 severity grades of AC criteria tended to underestimate the severity of gallbladder inflammation in patients with mild AC and overestimate the difficulty of LC in patients with moderate AC [10].

Our study differed from that of Ambe et al. in several ways. Firstly, we excluded patients who underwent $\mathrm{CTO}$ for exploration of $\mathrm{CBD}$ and used CTO as a proxy of surgical difficulty during LC. Secondly, we assessed the relationship between different histologic gallbladder pathology and CTO and found active chronic cholecystitis to have a higher rate of CT compared to patients with chronic cholecystitis and a similar CTO rate to acute edematous cholecystitis. Thirdly, we have shown that histology-based severity of AC is not only associated with increase in the rate of CTO, but also with major bile duct and bowel injury during LC.

Importantly, we have grouped patients with different histologic severity of AC according to their CTO rate into mild and moderate-severe AC. Mild AC included patients with active chronic cholecystitis and acute edematous cholecystitis. Patients with acute necrotizing, gangrenous, or suppurative cholecystitis, and those with pericholecystic abscess or gallbladder perforation had more severe histologic features of gallbladder inflammation and higher rates of CTO, therefore, they were included in the moderate-severe AC category. We have demonstrated that patients in the moderate-severe group not only had higher odds of CTO, but also had longer durations of surgery and increased rates and severity of peri-operative 


\begin{tabular}{|c|c|c|c|}
\hline Characteristics & $\begin{array}{l}\text { Histologic Mild AC, } \\
\mathrm{N}=305, \mathrm{n}(\%)\end{array}$ & $\begin{array}{c}\text { Moderate-severe } \mathrm{AC}, \mathrm{N}=167 \\
\mathrm{n}(\%)\end{array}$ & P-value \\
\hline Age (median, range), years & $55(18-92)$ & $61(17-91)$ & 0.0121 \\
\hline \multicolumn{4}{|l|}{ Gender, n (\%) } \\
\hline Male & 143 (46.9) & $102(61.1)$ & \\
\hline Female & $162(53.1)$ & 65 (38.9) & 0.003 \\
\hline \multicolumn{4}{|l|}{ Ethnicity, n (\%) } \\
\hline Caucasian & $237(77.7)$ & $131(78.4)$ & \\
\hline Maori & $19(6.2)$ & $7(4.2)$ & \\
\hline Pacific Islander & $15(4.9)$ & $6(3.6)$ & \\
\hline Asian & $18(5.9)$ & $9(5.4)$ & \\
\hline Others $\S$ & $16(5.3)$ & $14(8.4)$ & 0.563 \\
\hline \multicolumn{4}{|l|}{ Admission type, $\mathrm{n}(\%)$} \\
\hline Elective & $48(15.7)$ & $1(0.6)$ & \\
\hline Acute & $257(84.3)$ & $166(99.4)$ & $<0.0005$ \\
\hline Cholelithiasis & $285(93.4)$ & $154(92.2)$ & 0.617 \\
\hline \multicolumn{4}{|l|}{ Comorbidities, n (\%) } \\
\hline Hypertension & $95(31.2)$ & $61(36.5)$ & 0.235 \\
\hline TIA/stroke & $11(3.6)$ & $4(2.4)$ & 0.473 \\
\hline Angina & $20(6.6)$ & $16(9.6)$ & 0.0237 \\
\hline Previous MI & $18(5.9)$ & $14(8.4)$ & 0.305 \\
\hline Cardiac arrhythmia & $17(5.6)$ & $8(4.8)$ & 0.716 \\
\hline Heart failure & $8(2.6)$ & $4(2.4)$ & 0.881 \\
\hline Diabetes mellitus & $28(9.2)$ & $30(18.0)$ & 0.005 \\
\hline Previous abdominal operation, $\mathrm{n}(\%)$ & $58(19.0)$ & $26(15.6)$ & 0.349 \\
\hline $\begin{array}{l}\text { Number of previous abdominal operations } \\
\text { (median, range) }\end{array}$ & $1(1-2)$ & $1(1-4)$ & 0.53 \\
\hline \multicolumn{4}{|l|}{ ASA score, $n(\%)$} \\
\hline 1 & $86(28.2)$ & $28(16.8)$ & \\
\hline II & $159(52.1)$ & $81(48.5)$ & \\
\hline III & $55(18.0)$ & $51(30.5)$ & \\
\hline IV & $5(1.6)$ & $6(3.6)$ & \\
\hline V & $0(0)$ & $1(0.6)$ & 0.002 \\
\hline $\begin{array}{l}\text { AC, acute cholecystitis; TI } \\
\text { MI, myocardial infarction. }\end{array}$ & emic attack; ASA s & American Society of Anesthe & sts score; \\
\hline
\end{tabular}

complications including major injury to bile ducts and bowel. Based on these findings, we propose a histology-based clinical classification for AC.

It has been previously shown that inflammatory markers such as NLR and CRP can discriminate between these histology-based severity grades of AC [18, 19]. NLR cut off values of greater than 4.17 (95\% CI: 3.76-4.58) were found to distinguish between the histologic mild and moderate-severe categories that we have proposed. NLR areas under the receiver operating characteristic curves in moderate-severe AC was 98\% (95\% CI, 96\%-100\%) [19].

In a prospective study, Micic et al. demonstrated that NLR $\geq 4.18$ predicted severe AC defined as gallbladder inflammation, empyema, acute gangrenous cholecystitis and $\mathrm{AC}$ with gallbladder perforation, adhesions and difficulty in dissecting the Calot's triangle with $78.3 \%$ sensitivity and $74.3 \%$ specificity [13]. This means that in AC patients with NLR of 4.18 or above concerns are raised for increased surgical risks. $\mathrm{Pa}-$ tients with raised CRP and NLR should have a higher priori- ty for urgent LC than patients in the histology-based mild AC category [27]. More accurate prediction of clinical severity of AC using the histology-based approach should not only help with anticipation of surgical complexity, but also with management decisions that can include conservative versus surgical treatment in high-risk patients, prioritization of patients for surgery, allocation of surgical expertise for patients with moderate-severe AC, intensive care or high dependency unit bed occupancy booking and the choice and duration of antimicrobial medication.

Importantly, TG18 guidelines do not consider the histologic group of active chronic cholecystitis as a clinical variant of AC. These patients frequently have recurrent acute presentations with either cholecystitis or biliary colic. The risk of CTO in patients with active chronic cholecystitis was more than 5 times higher than for patients with chronic cholecystitis. We believe that patients with AC who are surgical candidates should benefit from LC being performed soon after their first episode of AC either as an acute or elective procedure. 
Our study is limited by its retrospective nature. Further prospective studies will enable more detail regarding clinical presentation and timing for patients in each of these groups.

In conclusion, increasing severity of histologic gallbladder inflammation corresponds with greater risk of CTO and higher rates and severity of postoperative complications. Patients with active chronic cholecystitis and acute edematous cholecystitis correspond to clinically mild AC and those with acute necrotizing, gangrenous, suppurative cholecystitis, pericholecystic abscess and $\mathrm{AC}$ with gallbladder perforation comprise clinically severe AC.

\section{Acknowledgements \\ Funding. No source of funding has been received for this} work.

Authors' contribution. A. M. Beliaev - contributed to the conception of the work, data collection and analysis and in writing the manuscript. N. Angelo - reviewed histological slides and made a structured histological report. C. Bergin, N. Angelo - and M. Booth - contributed with the study design, the interpretation of the data and critical revisions of the article.

Competing interests. The authors have no conflict of interest.

Consent for publication. All authors approved the paper to be published.

\section{Reference}

1. Glambek I, Kvaale G, Arnesjo B, Soreide O. Prevalence of gallstones in a Norwegian population. Scand J Gastroenterol. 1987;22(9):1089-94. PubMed PMID: 3321395.

2. Gracie WA, Ransohoff DF. The natural history of silent gallstones: the innocent gallstone is not a myth. N Engl J Med. 1982;307(13):798800. Epub 1982/09/23. doi: 10.1056/NEJM198209233071305. PubMed PMID: 7110244.

3. Friedman GD. Natural history of asymptomatic and symptomatic gallstones. Am J Surg. 1993;165(4):399-404. Epub 1993/04/01. PubMed PMID: 8480871.

4. Papadakis M, Ambe PC, Zirngibl H. Critically ill patients with acute cholecystitis are at increased risk for extensive gallbladder inflammation. World J Emerg Surg. 2015;10:59. Epub 2015/12/03. doi: 10.1186/ s13017-015-0054-1. PubMed PMID: 26628907; PubMed Central PMCID: PMC4666023.

5. Peery AF, Dellon ES, Lund J, Crockett SD, McGowan CE, Bulsiewicz WJ, et al. Burden of gastrointestinal disease in the United States: 2012 update. Gastroenterology. 2012;143(5):1179-87 e1-3. Epub 2012/08/14. doi: 10.1053/j.gastro.2012.08.002. PubMed PMID: 22885331; PubMed Central PMCID: PMC3480553.

6. Agresta F, Campanile FC, Vettoretto N, Silecchia G, Bergamini C, Maida P, et al. Laparoscopic cholecystectomy: consensus conference-based guidelines. Langenbecks Arch Surg. 2015;400(4):429-53. Epub 2015/04/09. doi: 10.1007/s00423-015-1300-4. PubMed PMID: 25850631.

7. Hirota M, Takada T, Kawarada Y, Nimura Y, Miura F, Hirata K, et al. Diagnostic criteria and severity assessment of acute cholecystitis: Tokyo Guidelines. J Hepatobiliary Pancreat Surg. 2007;14(1):78-82. Epub 2007/01/26. doi: 10.1007/s00534-006-1159-4. PubMed PMID: 17252300; PubMed Central PMCID: PMC2784516.

8. Yokoe M, Takada T, Strasberg SM, Solomkin JS, Mayumi T, Gomi $\mathrm{H}$, et al. TG13 diagnostic criteria and severity grading of acute cholecystitis (with videos). J Hepatobiliary Pancreat Sci. 2013;20(1):35-46.
Epub 2013/01/24. doi: 10.1007/s00534-012-0568-9. PubMed PMID: 23340953.

9. Yokoe M, Hata J, Takada T, Strasberg SM, Asbun HJ, Wakabayashi G, et al. Tokyo Guidelines 2018 diagnostic criteria and severity grading of acute cholecystitis (with videos). J Hepatobiliary Pancreat Sci. 2017. Epub 2017/10/17. doi: 10.1002/jhbp.515. PubMed PMID: 29032636.

10. Ambe PC, Christ H, Wassenberg D. Does the Tokyo guidelines predict the extent of gallbladder inflammation in patients with acute cholecystitis? A single center retrospective analysis. BMC Gastroenterol. 2015;15:142. Epub 2015/10/22. doi: 10.1186/s12876-015-0365-4. PubMed PMID: 26486453; PubMed Central PMCID: PMC4618467.

11. Yokoe M, Takada T, Hwang TL, Endo I, Akazawa K, Miura F, et al. Descriptive review of acute cholecystitis: Japan-Taiwan collaborative epidemiological study. J Hepatobiliary Pancreat Sci. 2017;24(6):319-28. Epub 2017/03/21. doi: 10.1002/jhbp.450. PubMed PMID: 28316140.

12. Chawla A, Bosco JI, Lim TC, Srinivasan S, Teh HS, Shenoy JN. Imaging of acute cholecystitis and cholecystitis-associated complications in the emergency setting. Singapore Med J. 2015;56(8):438-43; quiz 44. Epub 2015/08/28. doi: 10.11622/smedj.2015120. PubMed PMID: 26311909; PubMed Central PMCID: PMCPMC4545132.

13. Micic D, Stankovic S, Lalic N, Dukic V, Polovina S. Prognostic value of preoperative neutrophil-to-lymphocyte ratio for prediction of severe cholecystitis. J Med Biochem. 2018(37):1-7.

14. Moloney BM, Waldron RM, N OH, Kelly ME, Myers E, Garvin JT, et al. The clinical utility of pre-operative neutrophil-to-lymphocyte ratio as a predictor of outcomes in patients undergoing elective laparoscopic cholecystectomy. Ir J Med Sci. 2018. Epub 2018/01/26. doi: 10.1007/ s11845-018-1749-6. PubMed PMID: 29368279.

15. Beliaev AM, Booth M, Angelo N, Bergin C. Diagnostic Work-Up of Patients with Acute Cholecystitis. In: Powell L, editor. Acute Cholecystitis: Diagnosis, Management and Complications. Hepatology Research and Clinical Developments. New York: Nova Science Publishers, Inc.; 2016. p. 31-68.

16. Asai K, Watanabe M, Kusachi S, Matsukiyo H, Saito T, Kodama H, et al. Risk factors for conversion of laparoscopic cholecystectomy to open surgery associated with the severity characteristics according to the Tokyo guidelines. Surg Today. 2014;44(12):2300-4. Epub 2014/01/30. doi: 10.1007/s00595-014-0838-z. PubMed PMID: 24473668.

17. Cwik G, Skoczylas T, Wyroslak-Najs J, Wallner G. The value of percutaneous ultrasound in predicting conversion from laparoscopic to open cholecystectomy due to acute cholecystitis. Surg Endosc. 2013;27(7):25618. Epub 2013/02/02. doi: 10.1007/s00464-013-2787-9. PubMed PMID: 23371022; PubMed Central PMCID: PMCPMC3679415.

18. Beliaev AM, Marshall RJ, Booth M. C-reactive protein has a better discriminative power than white cell count in the diagnosis of acute cholecystitis. J Surg Res. 2015;198(1):66-72. doi: 10.1016/j.jss.2015.05.005. PubMed PMID: 26038247.

19. Beliaev AM, Angelo N, Booth M, Bergin C. Evaluation of neutrophil-to-lymphocyte ratio as a potential biomarker for acute cholecystitis. J Surg Res. 2017;209:93-101. doi: 10.1016/j.jss.2016.09.034. PubMed PMID: 28032577.

20.Pepys MB, Hirschfield GM. C-reactive protein: a critical update. J Clin Invest. 2003;111(12):1805-12. Epub 2003/06/19. doi: 10.1172/JCI18921. PubMed PMID: 12813013; PubMed Central PMCID: PMCPMC161431.

21. Strasberg SM, Hertl M, Soper NJ. An analysis of the problem of biliary injury during laparoscopic cholecystectomy. J Am Coll Surg. 1995;180(1):101-25. Epub 1995/01/01. PubMed PMID: 8000648.

22. Dindo D, Demartines N, Clavien PA. Classification of surgical complications: a new proposal with evaluation in a cohort of 6336 patients and results of a survey. Ann Surg. 2004;240(2):205-13. Epub 2004/07/27. PubMed PMID: 15273542; PubMed Central PMCID: PMC1360123.

23. Neugebauer E, Troidl H, Kum CK, Eypasch E, Miserez M, Paul A. The E.A.E.S. Consensus Development Conferences on laparoscopic cholecystectomy, appendectomy, and hernia repair. Consensus state- 
ments--September 1994. The Educational Committee of the European Association for Endoscopic Surgery. Surg Endosc. 1995;9(5):550-63. Epub 1995/05/01. PubMed PMID: 7676385.

24. Strasberg SM. Biliary injury in laparoscopic surgery: part 1. Processes used in determination of standard of care in misidentification injuries. J Am Coll Surg. 2005;201(4):598-603. Epub 2005/09/27. doi: 10.1016/j. jamcollsurg.2005.05.009. PubMed PMID: 16183500.

25. Jansen S, Doerner J, Macher-Heidrich S, Zirngibl H, Ambe PC. Outcome of acute perforated cholecystitis: a register study of over 5000 cases from a quality control database in Germany. Surg Endosc. 2017;31(4):1896900. Epub 2016/08/25. doi: 10.1007/s00464-016-5190-5. PubMed PMID: 27553799.
26. Yamashita Y, Takada T, Strasberg SM, Pitt HA, Gouma DJ, Garden OJ, et al. TG13 surgical management of acute cholecystitis. J Hepatobiliary Pancreat Sci. 2013;20(1):89-96. Epub 2013/01/12. doi: 10.1007/s00534012-0567-x. PubMed PMID: 23307007.

27. Beliaev AM, Booth M. C-reactive protein measurement is not associated with an improved management of acute cholecystitis: a plie for a change. J Surg Res. 2015;198(1):93-8. Epub 2015/06/23. doi: 10.1016/j. jss.2015.05.042. PubMed PMID: 26095425.

Надійшла 04.07.19 